\title{
Ethephon Tissue Penetration and Harvest Effectiveness in Olive as a Function of Solution pH, Application Time, and BA or NAA Addition
}

\author{
James O. Denney ${ }^{1}$ and George C. Martin ${ }^{2}$ \\ Department of Pomology, University of California, Davis, CA 95616-8683
}

\begin{abstract}
Additional index words. Olea europaea, abscission, (2-chloroethyl)phosphonic acid, phosphate, auxin, naphthalene acetic acid, cytokinin, 6-benzylaminopurine, benzyladenine, anthocyanin, autoradiography, ${ }^{14} \mathrm{C}$, osmium tetroxide
\end{abstract}

\begin{abstract}
Fruit removal force (FRF) and percent leaf drop (LD) of fruit-bearing olive (Olea europaea L.) shoots were examined 120 hours after being sprayed with ethephon at $600 \mathrm{mg}^{-l i t e r}{ }^{-1}$ and held under controlled-environmental conditions analogous to those found in the field in California at harvest time in mid-October. FRF was not significantly affected by solution pH, but FRF of all treated shoots was significantly lower than that of the untreated controls. Only at pH 5 was percent LD significantly greater than that of the controls, but, of the shoots treated with ethephon, the lowest percent $L D$ occurred at pH 3. Percent $L D$ after treatment with ethephon at pH 3 was not affected by application time, but FRF was significantly less than the controls' when shoots were treated at 7 AM or 12 PM but not at 5 PM or 10 PM. Adding NAA to the ethephon solution raised FRF and adding BA lowered FRF compared to ethephon alone. Adding NAA or BA did not mitigate percent LD significantly. Adding BA advanced anthocyanin production in fruit. Ethephon penetration of rachides was $\approx 70 \%$ that of petioles. Correlation between ethephon penetration of petioles and percent LD was greater than that between penetration of rachides and FRF. Correlation was significant for both tissues only in the 12 PM pH 3 treatment; correlation was also significant for petiole penetration and percent $\mathrm{LD}$ at $\mathrm{pH} 5$. Autoradiographic studies of the ${ }^{14} \mathrm{C}$-ethephon penetration showed no $\mathrm{pH}$ effect, greater penetration into petioles than rachides, and that radioactivity was limited largely to intercellular spaces, with accumulation in vascular bundles, especially xylem. Regardless of treatment, FRF and percent $L D$ are negatively correlated $\left(r^{2}=0.615\right)$. Mean results to be expected using ethephon as an olive harvest aid under these conditions are an $F R F$ of $\approx 3 \mathrm{~N}$ and a percent $L D$ of $\approx 15 \%$. The desired low FRF and percent LD were obtained by applying ethephon alone at pH 3 at 7 AM. Raising ethephon solution pH does not increase harvest effectiveness. Chemical names used: (2-chloroethyl)phosphonic acid (ethephon), naphthalene acetic acid (NAA), 6benzylaminopurine (BA).
\end{abstract}

Because harvest costs can account for as much as $60 \%$ of production costs, olive producers worldwide have long been interested in the possibility of using mechanical harvesters (Fridley et al., 1973; Hartmann, 1973; Lamouria and Hartmann, 1959; Lang and Martin, 1985; Martin et al., 1981). Mechanical olive harvest can be more efficient using chemical loosening agents to reduce fruit-removal force (FRF). Using such chemicals is especially important in California, where most olives are harvested before reaching physiological maturity, and, as a consequence, FRF is high (Hartmann et al., 1968; Hartmann et al., 1975; Martin et al., 1981). Several chemicals have been tested as fruit-abscission promoters, and the best results have been with ethylene-releasing chemicals (ERCs) (Hartmann, 1973; Hartmann et al., 1968; Hartmann et al., 1970, 1975, 1976; Lavee and Haskal, 1976; Jacobini and Tombesi, 1973; Martin et al., 1981; Polito and Stallman, 1981; Vitagliano, 1969). Only the ERC ethephon, which has been licensed for use in the United States on many edible crops (Kays and Beaudry, 1987), is likely to be approved for use on olive under present regulatory conditions. Despite its widespread use, ethephon, especially as used on perennial fruit trees, has plagued growers with inconsistent results (Beaudry and Kays, 1987).

When applied to olive, ethephon affects fruit and leaf abscission

Received for publication 3 Feb. 1994. Accepted for publication 4 May 1994. This research was funded in part by the California Olive Committee. We gratefully acknowledge the assistance of Douglas Adams, Peter Rock, Chic Nishijima, Katherine Pinney, Glenn Turner, and Vito Polito. From a dissertation submitted by J.O.D. in partial fulfillment of $\mathrm{PhD}$ requirements. The cost of publishing this paper was defrayed in part by the payment of page charges. Under postal regulations, this paper therefore must be hereby marked advertisement solely to indicate this fact. ${ }^{1}$ Deceased.

${ }^{2}$ Professor and pomologist. To whom reprints requests should be addressed.
(Lavee and Haskal, 1976; Lang and Martin, 1985, 1987, 1989). Leaf abscission is a serious problem because a loss $>25 \%$ can adversely affect return bloom (Hartmann, 1973) and the presence of leaf scars permits infection by Pseudomonas syringae pv. savastanoi Smith, the causal pathogen of olive-knot disease (Hewitt, 1938). Hartmann et al. (1970) applied NAA with ethephon to olive under field conditions and successfully decreased leaf abscission with less fruit loosening. Lang (1987) noted that, of the plant growth regulators, only cytokinins have not been tested for effects on olive fruit abscission. Martin et al. (1981) applied various forms of $\mathrm{Ca}$ in ethephon solutions to mitigate leaf loss; leaf loss was reduced, but FRF was increased.

Abscission studies conducted in the field under naturally variable environmental conditions are neither controlled nor repeatable and often lack statistical verification. Likewise, abscission studies conducted in the laboratory under controlled and repeatable conditions usually lack analogy to conditions under which the ERCs would be applied in the field. In the case of ethephon, this is a particularly critical problem. Temperature, relative humidity $(\mathrm{RH})$, and the $\mathrm{pH}$ of the water available for mixing the chemical can affect ethylene evolution rate as a result of ethephon decomposition and the extent of tissue penetration (Beaudry and Kays, 1987; Ben-Tal and Lavee, 1976a; Bukovac et al., 1969; Cooke and Randall, 1968; Flore and Bukovac, 1982; Kays and Beaudry, 1987; Klein et al., 1978, 1979; Lavee and Haskal, 1976; Maynard and Swan, 1963; Olien and Bukovac, 1978, 1982; Warner and Leopold, 1969; Yang, 1969).

Ethephon solutions have been buffered to $\mathrm{pH} 6.3$ and 7 to speed up ethylene release and mitigate olive leaf loss (Ben-Tal and Lavee, 1976a; Klein et al., 1979). Lavee and Haskal (1976) examined ethephon application in the field at different times of the 
day, but without conclusive results. Laboratory studies by Lang and Martin $(1985,1987)$ approached the problem of field analogy indirectly by examining ERC (including ethephon) ethylenerelease characteristics and organ response with precise application and using pulses of ethylene gas to model ethylene release from ERCs in the field.

Penetration of ERCs into plants and their subsequent movement within plant tissues can influence their effectiveness (Kays and Beaudry, 1987). Epstein et al. (1977) studied penetration of ${ }^{14} \mathrm{C}$-ethephon at $\mathrm{pH} 7$ in phosphate buffer into attached and detached olives and rachides (pedicels). More radiolabeled material was found in the fruit when ${ }^{14} \mathrm{C}$-ethephon was applied at the distal end of the fruit than when it was applied to the pedicel-fruit cavity. These authors concluded that ethephon movement was unidirectional out of the fruit and rachis toward the leaves. Lang and Martin (1986) studied stem-fed or sprayed ${ }^{31} \mathrm{P}$-ethephon penetration into olive leaves using nuclear magnetic resonance (NMR). Ethephon peaks disappeared and phosphate peaks appeared in a negative linear relationship. However, the lower limit for detecting ethephon using NMR was several times the concentration used in agricultural situations.

This research was undertaken with three purposes in mind. The first purpose was to develop an experimental system that was controlled and analogous to field conditions. The second was to test the following hypotheses: a) solution $\mathrm{pH}$ affects olive FRF and percent LD, b) application time (as an expression of temperature and $\mathrm{RH}$ ) affects FRF and percent $\mathrm{LD}, \mathrm{c}$ ) ethephon penetration influences ethephon's effects on FRF and percent LD, and d) applying NAA or BA with ethephon can help mitigate percent LD. The third was to define the harvest effectiveness of ethephon on olive.

\section{Materials and Methods}

The olive inflorescence is complex; its structure has been redefined by Weis et al. (1988, 1991). In the present discussion, rachis is the fruit stem, the pedicel is the point of attachment of the rachis to the fruit, and the peduncle is the thickened portion of the rachis where it attaches to the stem.

Experiments were conducted at 3- to 4-week intervals beginning in late August and ending in early December 1990 and 1991. Fruit-bearing 'Manzanillo' olive shoots were excised in the early morning from trees of the Univ. of California Dept. of Pomology research orchards at Davis, and the proximal ends were placed in a bucket of water. In 1990, each shoot bore at least six rachides; because of the reduced yields following a damaging freeze in December 1990 (Denney et al., 1993), the lower limit was reduced to four rachides in 1991. Most rachides bore one fruit, but many rachides bore two or more fruit. After transport to the growth chamber facility, each shoot was processed to reduce transpiration by removing all tissue beginning at the second node distal to the fruiting area. An upper limit of 10 rachides per shoot was used for 1990 and 1991: any rachides or leaves proximal to the selected fruiting area were removed, but the main stem was retained. The bases of these shoots were recut under running deionized water, then placed in $40-\mathrm{ml}$ vials containing a solution of 8hydroxyquinoline citrate (8-HQC) at $200 \mathrm{mg} \cdot \mathrm{liter}^{-1}$. 8-HQC is a bactericide used to improve shoot quality and holding time.

Each treatment unit contained six shoots, with a mean of 53.9 fruit and 49.1 nodes per treatment unit. Generally, there were two leaves per node, but there were occasionally three. The treatments were as follows.

Solution $\mathrm{pH}$. The treatment units were sprayed with a solution of ethephon in deionized water at a concentration of $600 \mathrm{mg} \cdot \mathrm{liter}$ ${ }^{1}$ to discern differences among experimental conditions. Concentrations of 900 to $1200 \mathrm{mg} \cdot$ liter $^{-1}$, which are used in the field, usually reduced mean FRF to below $1.5 \mathrm{~N}$ and it was difficult to differentiate between the various treatments being tested. The $\mathrm{pH}$ of each solution to be applied was raised from 2.5 using crushed solid $\mathrm{KOH}$ and adjusted with $1 \mathrm{~N} \mathrm{HCl}$ to $\mathrm{pH} 3,5$, and 7. The three solutions were sprayed on the shoots in the appropriate treatment unit at 5 PM using a hand-pumped household spray bottle in 1990 and an aerosol-spray bomb in 1991. In 1990, cuttings were sprayed to run-off. In 1991, exactly $40 \mathrm{ml}$ of solution was applied to each treatment unit, resulting in complete coverage as indicated by dripoff. A control unit of six shoots was left untreated.

Application time. Using methods described above, a solution of ethephon at $600 \mathrm{mg} \cdot \mathrm{liter}^{-1}$ and $\mathrm{pH} 3$ was sprayed on separate treatment units at 5:00 PM, 10:00 PM, 7:00 AM, and 12:00 PM. Two control units of six shoots each were left untreated for processing after $120 \mathrm{~h}$ at 5:00 $\mathrm{PM}$ and 12:00 PM.

BA or NAA addition. Using methods described above, solutions of ethephon at $600 \mathrm{mg} \cdot \mathrm{liter}^{-1}$ and $\mathrm{pH} 3$ were prepared from solutions of BA at 25,50 , and $100 \mathrm{mg} \cdot$ liter $^{-1}$ solubilized in warm distilled water. Concentrations of BA at 125, 200, 250, and 500 $\mathrm{mg} \cdot$ liter $^{-1}$ were achieved by adding small amounts of BA solubilized in warm $80 \%$ methanol to an ethephon solution at $\mathrm{pH} 3$. The $\mathrm{K}$ salt of NAA (NAA-800) at concentrations of 125, 250, 500, 1000,2000 , or $2500 \mathrm{mg} \cdot$ liter $^{-1}$ was added to solutions of ethephon at $\mathrm{pH} 3$ and a concentration of $600 \mathrm{mg} \cdot \mathrm{liter}^{-1}$. Final solution $\mathrm{pH}$ was monitored for all solutions. The sprays with these added chemicals were applied on two dates at 5:00 PM and on three dates at 12:00 PM. Control units of six shoots were left untreated at each application time. Additional controls using solutions of BA and NAA alonethat is, without ethephon-were also used.

Control chamber to simulate field conditions. Olive shoots were placed in a growth chamber fitted with a temperature controller. This controller has ramp-and-soak functions that allow the chamber temperature to follow a diurnal sine wave pattern, with a nighttime minimum of 10C at 5:00 $\mathrm{Am}$ and a daytime maximum of 30C at 2:00 PM. This diurnal pattern is about the average found at olive-producing sites in California's Central Valley during midOctober, the optimum time for olive harvest (Denney, 1982; Sibbett et al., 1986). In 1990, RH was controlled using the built-in growth chamber controls, with an abrupt change from a nighttime $\mathrm{RH}$ of $80 \%$ to a daytime RH of $30 \%$ and back again at 7:00 AM and 7:00 PM, respectively. In 1991, a temperature controller with rampand-soak functions was installed on the growth chamber for RH functions. This allowed the programming of a $\mathrm{RH}$ pattern that was also a diurnal sine wave-but the mirror image for that for temperature - with a nighttime maximum of $80 \%$ at 5:00 AM and a daytime minimum of $30 \%$ at 2:00 PM, also about that found in California's Central Valley in mid-October. Chamber temperature and $\mathrm{RH}$ were monitored and recorded using a datalogger equipped with a temperature-RH probe. Incandescent and fluorescent lamps in the growth chamber were turned on at 7:00 AM and turned off at 7:00 PM.

Treated units and untreated controls were harvested after $120 \mathrm{~h}$. The six shoots of each treatment were placed in a plastic bag for transport to the laboratory. In the laboratory, FRF was measured by attaching a hood connected to a hand-held dynamometer to each fruit, which was then pulled off its rachis. FRF was measured as kilograms of force, which was later converted to Newtons. Any fruit that dropped without being attached to the dynamometer were also assigned an FRF of $0.005 \mathrm{~kg}$ each. Most of these dropped fruit could not be assigned with any certainly to a particular shoot of the 
six in the treatment unit. LD was calculated as a percent of leaves present. After fruit removal, a cupped hand was passed up and down the stem twice. The number of leaves that dropped was recorded and added to the number of leaves that had dropped of their own accord.

Ethephon tissue penetration. After FRF and percent LD were measured, all rachides and leaves not already removed were taken off the shoots, and the denuded shoots were discarded. Separately, leaves and rachides for each solution $\mathrm{pH}$ and application time were washed to remove external ethephon residues by swirling for $1 \mathrm{~min}$ in a $0.05 \%$ solution of Tween-20 detergent in deionized water and rinsing thoroughly in running deionized water. Each group of leaves and rachides was placed in separate plastic bags and refrigerated at $\approx 4$ C overnight for processing the next day. In 1990, two $0.5-\mathrm{g}$ petiole and rachide samples were taken. For the rachis, larger portions of the peduncle and pedicel ends, where abscission zones form, were taken than of the middle of the rachis. Each 0.5$\mathrm{g}$ sample was macerated in $10 \mathrm{ml}$ distilled water using a polytron. In 1991, a 1-g sample of each tissue type from the treatments was macerated in $20 \mathrm{ml}$ distilled water. The macerated mixture was centrifuged at $\approx 2500 \mathrm{rpm}$ for $3 \mathrm{~min}$. The supernatant was filtered under vacuum using Whatman's no. 1 paper. In 1990, three 1-ml aliquots of the filtrate were taken for each 0.5-g sample. In 1991, four 1-ml aliquots of the filtrate were taken for each 1-g sample. Each aliquot was placed in a 50-ml culture tube, and $1 \mathrm{ml}$ of a $1 \mathrm{M}$ $\mathrm{KOH}$ solution was added to each to raise the $\mathrm{pH}$ to $\approx 11.5$, at which level virtually all ethephon molecules are in the dianion form and ethephon decomposes and ethylene evolves rapidly (Biddle et al., 1976). The culture tubes were covered with rubber-septum stoppers and allowed to incubate at $\approx 20 \mathrm{C}$ for $24 \mathrm{~h}$. After thorough mixing, a 10-ml gas sample was taken to estimate ethylene using a gas chromatograph fitted with a 2-ml loop, an alumina 60/80 mesh column at $80 \mathrm{C}$, and a single flame ionization detector.

Autoradiography. Nine shoots containing at least four fruitbearing rachides each were selected from field trees once in January 1992 and processed as described above. Ethephon spray solutions were prepared by mixing a solution of $1,2-{ }^{14} \mathrm{C}-(2-$ chloroethyl)phosphonic acid (Amersham Lot CFQ 5661, dated 12 Oct. $1990 ; 85 \mu \mathrm{l} ; 55 \mu \mathrm{Ci} ; 46 \mathrm{mCi} \cdot \mathrm{mM}^{-1}$; radiopurity $>97.5 \%$ ) into a regular solution of ethephon in deionized water to produce an effective concentration of $600 \mathrm{mg} \cdot \mathrm{liter}^{-1}$. Three 40-ml samples of this ${ }^{14} \mathrm{C}$-ethephon-spiked solution were taken, and $\mathrm{pH}$ was adjusted to 3, 5, and 7, respectively, using crushed solid $\mathrm{KOH}$ and $1 \mathrm{~N} \mathrm{HCl}$. Three shoots each were sprayed at each $\mathrm{pH}$ using a hand-pumped sprayer inside a plastic bag at 4:00 PM. After spraying, shoots were returned to the $8-\mathrm{HQC}$ solution. The tub containing the nine shoots was placed inside a containment chamber through which air was drawn using a vacuum pump at a flow rate of $300 \mathrm{ml} \cdot \mathrm{min}^{-1}$. Air exiting the containment chamber was passed over granules coated with potassium permanganate to scrub radiolabeled ethylene before venting into the environment. Temperature and RH were monitored using a datalogger equipped with a temperature-RH probe installed in the inlet to the containment chamber. Growth chamber lights were left off during the experiment to avoid any greenhouse effect in the containment chamber.

Shoots were harvested after $120 \mathrm{~h}$, in keeping with the $\mathrm{pH}$ experiments described above. Shoots were removed from the containment chamber and immediately placed in plastic bags for disposal. Each of the three groups of three shoots was washed separately for $2 \mathrm{~min}$ in a solution of $0.05 \%$ Tween-20 in deionized water, then rinsed twice in deionized water. The cuttings were refrigerated overnight for processing the next day. The following afternoon, distal portions of the rachides including pedicels and proximal portions of the petioles still attached to the stem were excised from the washed shoots. The abscission zones form in these areas in the olive. These portions were cut into sections $\approx 1$ mm long.

Samples were divided into groups by tissue (rachis, pedicel, petiole, or petiolar abscission zone), solution $\mathrm{pH}(3,5$, or 7$)$, and fixation treatment with $\mathrm{OsO}_{4}$ vapor from $\mathrm{OsO}_{4}$ dissolved in water held in a film cartridge capsule lid in a covered petri dish with a moist filter paper on the bottom (to prevent excessive tissue dehydration) for $0.5 \mathrm{~h}$. Osmium tetroxide is a powerful oxidizer that has a special attraction to lipids; it is used in electron microscopy to provide detailed staining of membranes, which contain phospholipids. Osmium tetroxide will also stain a variety of other tissues; it is effective in attacking double bonds, such as those found in ethephon and ethylene.

After fixation, samples were dehydrated in a $10 \%$ to $100 \%$ ethanol series twice, then in a 3 propylene oxide : 1 ethanol (v/v) series, and finally in propylene oxide and resin using a Spurr's resin kit. Resin embedding with continuous mixing continued for $24 \mathrm{~h}$ before the samples in resin were allowed to harden in aluminum pans. Sections ( $2 \mu \mathrm{m}$ thick) of the various tissue samples were taken using an automated microtome. Sections were applied to drops of distilled water on $80-\mathrm{mm}$ glass slides with $20-\mathrm{mm}$ etched glass ends. No bonding material was used.

The slides were coated with a specialized autoradiographic emulsion diluted $1: 1(\mathrm{v} / \mathrm{v})$ with $0.6 \mathrm{M}$ ammonium acetate dissolved in double deionized water in complete darkness and placed in lighttight boxes with a desiccator material. The boxes were covered with aluminum foil and placed in a refrigerator at $\approx 4 \mathrm{C}$ for 3 weeks to expose the emulsion. In complete darkness, the slides were developed using developer diluted 1:1 (v/v) with double-deionized water and fixed. Slides were counterstained using Toluidine Blue $\mathrm{O}$, rinsed in deionized water, and mounted in glycerol. Slides were viewed and photographed using a photomicroscope.

\section{Results and Discussion}

Solution $\mathrm{pH}$. Ethephon solution $\mathrm{pH}$ did not significantly affect FRF of the treated shoots, but all were significantly different from the control (Table 1). Percent LD was significantly different from control only at $\mathrm{pH}$ 5. Ethephon penetration of rachides was variable, and none of the treated shoots was different from the untreated control (Table 1). There was increasing mean penetration of ethephon in petioles with increasing $\mathrm{pH}(r=0.99)$, but only pH 7 was significantly different from the control. Overall, rachis penetration was only $\approx 70 \%$ of the petiole penetration, a fact that seems to agree with studies indicating that penetration is generally less in fruit tissue than in vegetative tissue (Kays and Beaudry, 1987). This also agrees with the work of Reed and Hartmann (1976) and Polito and Lavee (1980) concerning the different surface characteristics of the areas at which petiole and pedicel abscission zones form. As expected, a negative relationship existed between ethephon penetration and FRF. Likewise, the correlations for percent LD and the petiole penetration showed no particular pattern, but there is a significant correlation $(r=0.92)$ at $\mathrm{pH}$ 5. This result reinforces the significance of the increase in percent $\mathrm{LD}$ at $\mathrm{pH} 5$ seen in Table 1 . Why this is the case is unclear, but it may relate to the $\mathrm{pH}$ of intercellular spaces, normally $\approx 4.5$, which is closer to 5 than to 3 or 7 .

These data contradict much of the literature associated with ethephon use on olive. Researchers have reported that raising $\mathrm{pH}$ from 3 to $\approx 7$ decreased FRF, presumably because of the more rapid release of ethylene from ethephon at that $\mathrm{pH}$ (Ben-Tal and Lavee, 
Table 1. Effect of solution $\mathrm{pH}$ of ethephon at $600 \mathrm{mg} \mathrm{liter}^{-1}$ applied at 5 PM on fruit-removal force (FRF), percent leaf drop (LD), and ethylene evolved as a measure of ethephon penetration of target organ. Values are \pm SD.

\begin{tabular}{|c|c|c|c|c|}
\hline \multirow[b]{2}{*}{$\mathrm{pH}$} & \multirow{2}{*}{$\begin{array}{l}\text { FRF } \\
(\mathrm{N})\end{array}$} & \multirow{2}{*}{$\begin{array}{l}\text { LD } \\
(\%)\end{array}$} & \multicolumn{2}{|c|}{$\begin{array}{c}\text { Ethylene evolved } \\
\left(\mu \mathrm{l} \cdot \text { liter } \cdot \mathrm{h}^{-1} \cdot \mathrm{g}^{-1} \text { fresh weight }\right)\end{array}$} \\
\hline & & & Rachis & Petiole \\
\hline 3 & $3.2 \pm 1.7 \mathrm{~b}^{\mathrm{z}}$ & $9.7 \pm 6.7 \mathrm{ab}$ & $5.7 \pm 7.6 \mathrm{a}$ & $4.5 \pm 3.7 \mathrm{ab}$ \\
\hline 5 & $2.9 \pm 2.1 \mathrm{~b}$ & $20.0 \pm 21.7 \mathrm{a}$ & $3.3 \pm 2.2 \mathrm{a}$ & $6.1 \pm 4.5 \mathrm{ab}$ \\
\hline 7 & $2.7 \pm 1.3 b$ & $15.0 \pm 14.1 \mathrm{ab}$ & $5.0 \pm 3.2 \mathrm{a}$ & $8.6 \pm 6.7 \mathrm{a}$ \\
\hline Control & $5.0 \pm 0.7 \mathrm{a}$ & $3.3 \pm 3.0 \mathrm{~b}$ & $1.0 \pm 1.2 \mathrm{a}$ & $1.1 \pm 1.1 \mathrm{~b}$ \\
\hline
\end{tabular}

${ }^{\mathrm{z}}$ Mean separation within columns at $P=0.05$ using Duncan's multiple range test.

1976a, 1976b). A body of literature has evolved based on this point, and the presumed pulse of ethylene that comes from ethephon decomposition as the daily temperature rises in the field increases the decomposition rate (Epstein et al., 1977; Klein et al., 1978, 1981). In most cases in which ethephon was used, the $\mathrm{pH}$ was raised using phosphate buffers. Klein et al. (1978) used either phosphate buffer or $\mathrm{NaOH}$ to raise the $\mathrm{pH}$, but they did not distinguish results based on this characteristic. Recent work in our laboratory indicated that phosphate alone has a pronounced effect on olive leaf and fruit abscission (Banno et al., 1993; Tiefengraber et al., 1994), and we conclude that the decrease in FRF seen at the higher $\mathrm{pH}$ under these circumstances is due, at least in part, to the action of phosphate in conjunction with that of ethylene from ethephon, rather than increased ethephon decomposition.

Autoradiography. In the autoradiographic studies, the presence of ${ }^{14} \mathrm{C}$ exclusively in ethephon was not established, therefore the term radioactivity will be used when referring to presence of label in autoradiographs. No differences in ethephon penetration as a function of solution $\mathrm{pH}$ could be determined. Tissue type was more important for determining extent of penetration. Most radioactivity seemed to be associated with vascular tissue. Radioactivity was found in the intercellular spaces of petiolar abscission zone (Fig. 1A) and was associated with xylem tracheids in attending tissue (Fig. 1B). Radioactivity was also found in the intercellular spaces of mostly xylem tissue in the vascular bundles of pedicels (Fig. 1C) with less found in the pith (Fig. 1D). Overall, the most radioactivity was found in pedicels rather than in other tissue types. These studies make clear what has long been suspected. Best results in terms of reducing FRF are obtained when ethephon is applied to the cavity at the pedicel-fruit junction, and ethephon solution naturally accumulates in this spot when the chemical is sprayed on the tree (Epstein et al., 1977; Lang and Martin, 1987). This accumulation likely means that more chemical penetrates into the tissue at this place than in other tissues.

Epstein et al. (1977) found that there was movement of ethephon in the olive rachis, and they theorized that movement was unidirectional from the fruit to the leaves. The clear association of ethephon with vascular tissues in the present study supports this theory. However, our study shows a clear association of ethephon with the xylem. It is possible that radioactivity seen in the xylem tissue remains there because of lack of ethephon transport. It seems far more likely, however, that the presence of ethephon in the xylem indicates that these tissues are involved in the chemical's transport. It is possible, but not likely, that movement from the fruit to the leaves as proposed by Epstein et al. (1977) takes place in the xylem. However, these authors point out that olives shrivel under water stress, and they imply that loss of water to the leaves rather than through fruit lenticels is the cause of this shrivel. This notwithstanding, the movement of materials away from a strong sink such as the fruit would more likely take place in the phloem. However, no support that phloem transports ethephon emerged in this study.
Application time. None of the four timed applications of ethephon at $\mathrm{pH} 3$ differ from each other in terms of FRF, but two of these, 7 AM and 12 PM, were different from the controls (Table 2). Despite the wide disparities in the percent LD means, there were no significant treatment effects. Ethephon tissue penetration as gauged by ethylene evolution did not differ from treatment to treatment, but rachis penetration was only $\approx 70 \%$ of that of petioles (Table 2).

Correlations between tissue penetration and FRF and percent LD are significant only at $12 \mathrm{PM}(r=-0.95$ and 0.98 , respectively). The low FRF and high percent LD at 12 PM and the close correlation of these parameters with ethephon penetration may be the result of higher temperature or lower RH. The results tend to agree with those of Klein et al. (1978), who showed acceptable FRF and moderate leaf loss at moderate temperatures and higher RH than at higher temperatures and low RH. The key to ethephon's penetration may be the level of daily hydration. Water accumulates repeatedly in the pedicel-fruit cavity at $7 \mathrm{Am}$ when $\mathrm{RH}$ is high, thereby allowing dried ethephon to redissolve on the surface and increasing the probability of its penetration. However, this same rehydration occurs on the petiole when the cuticle is most resistant, decreasing the probability of its penetration. This process may repeat for both tissues day after day as the pattern of low temperature and high RH is repeated. Nevertheless, the difference in response to the application time suggests that the environmental conditions under which the initial application is made are most important. That stomata are more likely to be open at 12 PM and 7 AM may also affect ethephon leaf penetration and degree of abscission (Flore and Bukovac, 1982). However, the data presented here (Table 2) showing a similar change in degree of ethephon penetration of rachis and petiole at 12 PM indicate that changes in surface characteristics are probably more important.

Addition of BA or NAA. FRF for treatments with NAA or BA added to ethephon solution were not different from treatments with ethephon alone (Table 3). However, since the treatments with NAA and BA added are significantly different from each other, some effect on fruit and leaf abscission is apparent. BA decreased and NAA increased FRF compared to ethephon alone. Neither NAA or BA affected percent LD. Overall, NAA or BA concentration seems to have made little difference in terms of FRF or percent LD.

To summarize results with regard to our experimental hypotheses, 1) $\mathrm{pH}$ of applied ethephon solutions did not affect FRF, but pH 5 negatively affected percent LD compared to the control; 2) applying ethephon at 7 AM or 12 PM lowers FRF significantly but applying it at 5 PM or 10 PM does not lower FRF significantly compared to the control; percent LD was not significantly affected by application time; 3 ) adding BA or NAA to the ethephon solution did not mitigate percent LD significantly compared to ethephon alone, and 4) penetration studies did not clarify the effect of this factor in ethephon use on olive, but significant correlations with percent $\mathrm{LD}$ at $\mathrm{pH} 5$ and with FRF and percent $\mathrm{LD}$ at $\mathrm{pH} 3$ applied 

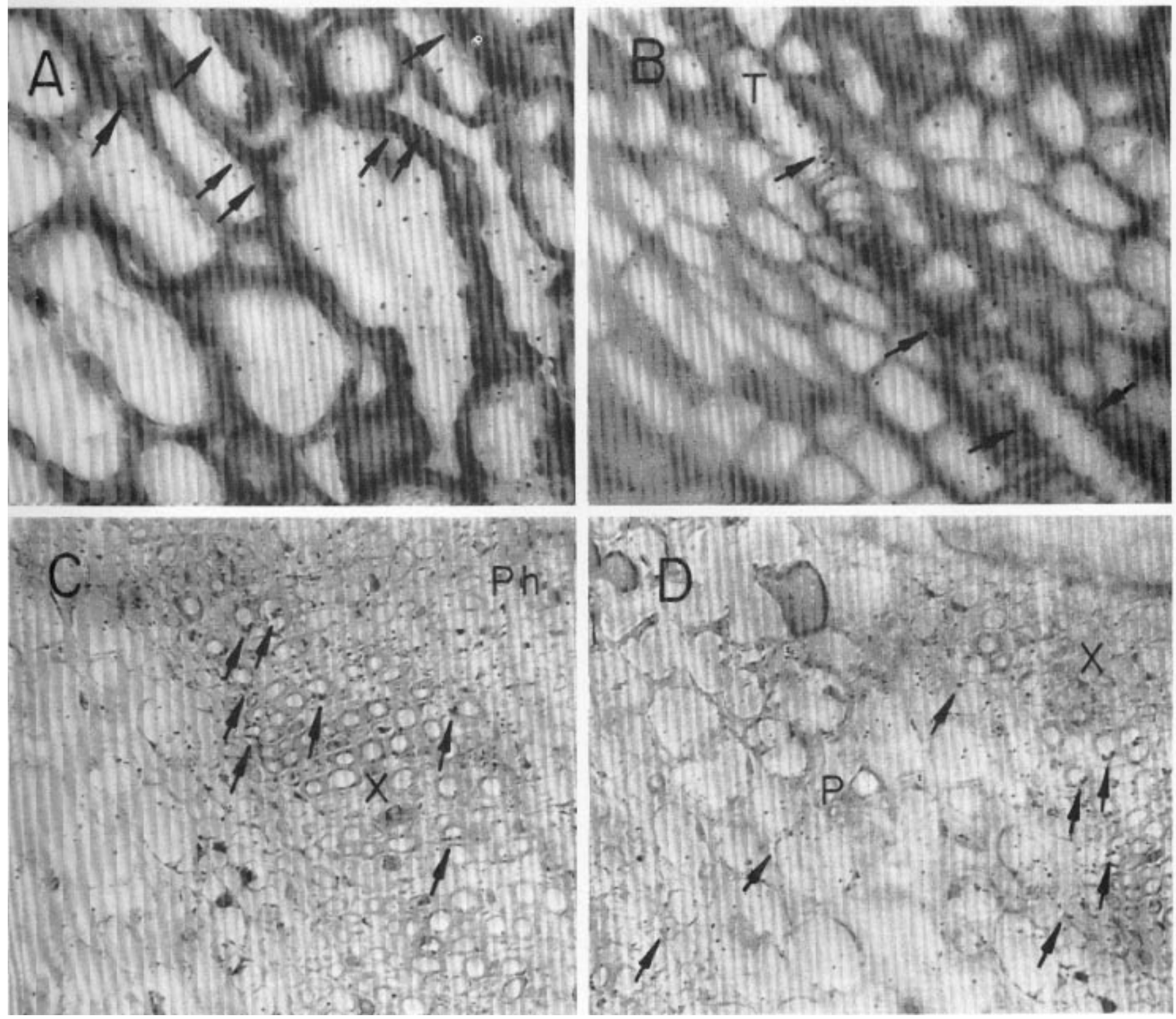

Fig. 1. (A) Ethephon in intercellular spaces in a petiolar abscission zone $(\times 157)$. Some silver grains, especially those in the cell lumens (bound ethylene?) are probably from background, but others in groups (arrows) are signs of radiolabeled ethephon. (B) Longitudinal section of a petiolar abscission zone xylem tracheid (T) $(\times 157)$ Some of the silver grains seen in the print are probably from background, but the groups of silver grains along the tracheid running from top left to bottom right (arrows) are from radiolabeled ethephon. (C) Cross section of a pedicel ( $\times 98)$. More silver grains are found around the xylem vessels (X) (large lumens) running from right to left than in the phloem $(\mathrm{Ph})(\mathbf{D})$ Cross section of a pedicel $(\times 98)$. Relatively few silver grains (arrows) indicating the presence of radiolabeled ethephon appear in the pith $(\mathrm{P})$ in the center as compared to the xylem $(\mathrm{X})$ and other vascular tissue at top and bottom.

Table 2. Effect of application time of ethephon at $600 \mathrm{mg} \cdot \mathrm{liter}^{-1}$ and $\mathrm{pH} 3$ on fruit-removal force (FRF), percent leaf drop (LD), and ethylene evolved as a measure of ethephon penetration of target organ. Values are \pm SD.

\begin{tabular}{lcccc}
\hline \hline & & & \multicolumn{2}{c}{$\begin{array}{c}\text { Ethylene evolved } \\
\left(\mu \mathrm{l} \cdot \text { liter }^{-1} \cdot \mathrm{g}^{-1} \text { fresh weight }\right)\end{array}$} \\
\cline { 2 - 5 } Time $(\mathrm{h})$ & FRF & LD & Rachis & Petiole \\
\hline $5 \mathrm{PM}$ & $(\mathrm{N})$ & $17.5 \pm 17.1 \mathrm{a}$ & $1.4 \pm 0.7 \mathrm{a}$ & $2.2 \pm 0.7 \mathrm{a}$ \\
$10 \mathrm{PM}$ & $3.2 \pm 1.9 \mathrm{ab}^{\mathrm{z}}$ & $16.2 \pm 11.2 \mathrm{a}$ & $1.6 \pm 1.4 \mathrm{a}$ & $2.3 \pm 1.7 \mathrm{a}$ \\
$7 \mathrm{AM}$ & $3.8 \pm 0.8 \mathrm{ab}$ & $10.2 \pm 10.6 \mathrm{a}$ & $1.2 \pm 0.7 \mathrm{a}$ & $2.1 \pm 0.7 \mathrm{a}$ \\
$12 \mathrm{PM}$ & $2.9 \pm 0.9 \mathrm{~b}$ & $23.1 \pm 4.4 \mathrm{a}$ & $2.5 \pm 2.0 \mathrm{a}$ & $3.2 \pm 0.9 \mathrm{a}$ \\
Control & $2.4 \pm 1.1 \mathrm{~b}$ & $6.0 \pm 11.0 \mathrm{a}$ & $1.3 \pm 1.7 \mathrm{a}$ & $1.4 \pm 1.6 \mathrm{a}$
\end{tabular}

${ }^{\mathrm{z}}$ Mean separation within columns at $P=0.05$ using Duncan's multiple range test. 
Table 3. Effect of adding NAA or BA to ethephon at $600 \mathrm{mg} \cdot$ liter $^{-1}$ and $\mathrm{pH} 3$ on fruit-removal force (FRF) and percent leaf drop (LD). Values are \pm SD.

\begin{tabular}{lcc}
\hline \hline & FRF & LD \\
Treatment & $(\mathrm{N})$ & $(\%)$ \\
\hline Ethephon + BA (50 mg.liter ${ }^{-1}$ ) & $2.0 \pm 1.7 \mathrm{c}^{\mathrm{z}}$ & $17.3 \pm 11.7 \mathrm{a}$ \\
Ethephon + BA (all concentrations) & $2.0 \pm 1.3 \mathrm{c}$ & $17.0 \pm 14.6 \mathrm{a}$ \\
Ethephon & $2.8 \pm 1.6 \mathrm{bc}$ & $15.8 \pm 10.8 \mathrm{a}$ \\
Ethephon + NAA (500 mg.liter ${ }^{-1}$ ) & $3.8 \pm 1.0 \mathrm{ab}$ & $7.6 \pm 7.7 \mathrm{a}$ \\
Ethephon + NAA (all concentrations) & $3.9 \pm 0.9 \mathrm{ab}$ & $9.5 \pm 8.9 \mathrm{a}$ \\
Control & $4.8 \pm 0.7 \mathrm{a}$ & $5.4 \pm 8.6 \mathrm{a}$ \\
\hline
\end{tabular}

${ }^{\mathrm{z}}$ Mean separation at $P=0.05$ using Duncan's multiple range test.

at 12 PM suggest that it is an important factor. Autoradiographic studies suggest that xylem transports ethephon in olive and that ethephon accumulation is greater in pedicel tissue than in other tissues.

Harvest effectiveness. The literature on ethephon as an olive harvest aid generally deals in terms of reduced FRF, and percent LD is either ignored completely or discounted (Ben-Tal and Lavee, 1976a, 1976b; Klein et al., 1978). Leaf drop may not even be mentioned, and, if it is, it is rarely quantified. An exception is the work of Lang and Martin (1987, 1989), who used fruit-to-leaf abscission ratios when evaluating ERCs and gaseous ethylene treatments. Percent LD is an important factor in deciding the effectiveness of chemical harvest aids on olive because of the importance of leaves for return bloom and because of the threat of olive-knot disease infection (Hartmann, 1973, Hewitt, 1938; Lang and Martin, 1987). In our results, different treatments that produced similar results in terms of FRF did not have similar results in terms of percent LD. This was especially true when the $\mathrm{pH}$ of the ethephon solution is considered (Table 1).

There is, however, another important reason to include percent LD along with FRF in any definition of harvest effectiveness of ethephon on olive. These two parameters are inextricably related. For example, FRF declines as percent LD increases in controls compared over time (Fig. 2). Also, when all the treatments tested in the present studies are considered together, a very clear pattern emerges: there is a negative linear relationship between FRF and percent $\mathrm{LD}\left(r^{2}=0.615\right)$. This relationship is true for the controls for treatments using ethephon alone or in treatments using ethephon with growth regulators added (Fig. 3).

At a FRF of 1 N, 100\% fruit drop does not result in $100 \%$ leaf drop because leaf petioles and fruit rachides do not respond identically to ethylene. Lang and Martin (1985) previously suggested that pedicel and petiole tissues have different sensitivities to ethylene, with the pedicel tissues responding more quickly and for less time than the leaf tissue. It may also be that the more conservative response to ethylene found in leaf tissue allows for a wider variation in responsiveness brought about by other factors, such as tissue age and environmental conditions.

Harvest effectiveness under the conditions established for these experiments can be seen as a convergence between decreasing FRF and increasing percent LD. The point of convergence that emerges from our data is a FRF of $3.0 \pm 0.6 \mathrm{~N}$ and a percent $\mathrm{LD}$ of $14.7 \pm 4.4 \%$. A FRF of $\approx 3 \mathrm{~N}$ should allow for $\approx 85 \%$ fruit removal, an acceptable level for commercial production. It also seems likely that anything added to mitigate leaf abscission, such as auxins or Ca compounds, will have a similar effect on fruit abscission (Hartmann et al., 1970;

\section{Untreated Controls 1991}

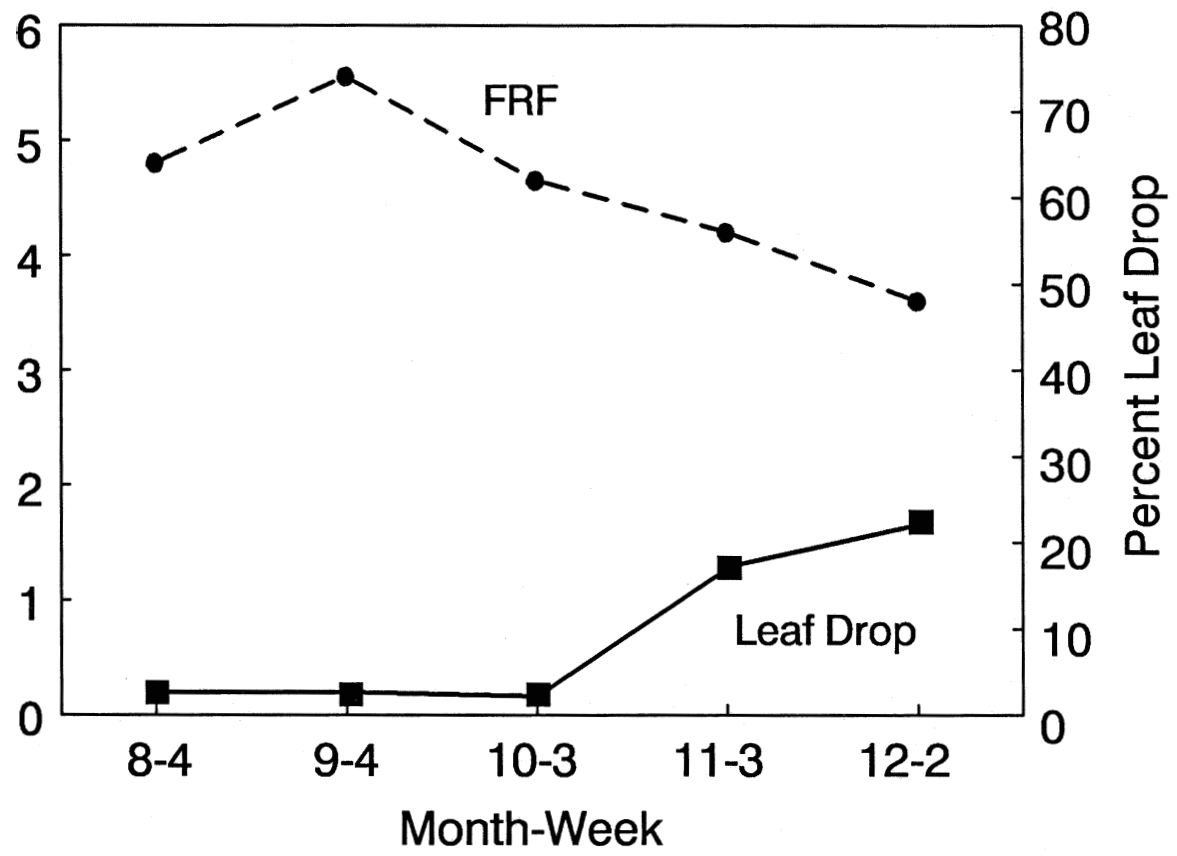

Fig. 2. Fruit-removal force (FRF) and percent leaf drop for controls, 1991. In the olive shoots not treated with ethephon, mean FRF declined slowly from late summer to late autumn, whereas mean percent leaf drop increased over the same period. 


\section{Bivariant Plot of Parameters}

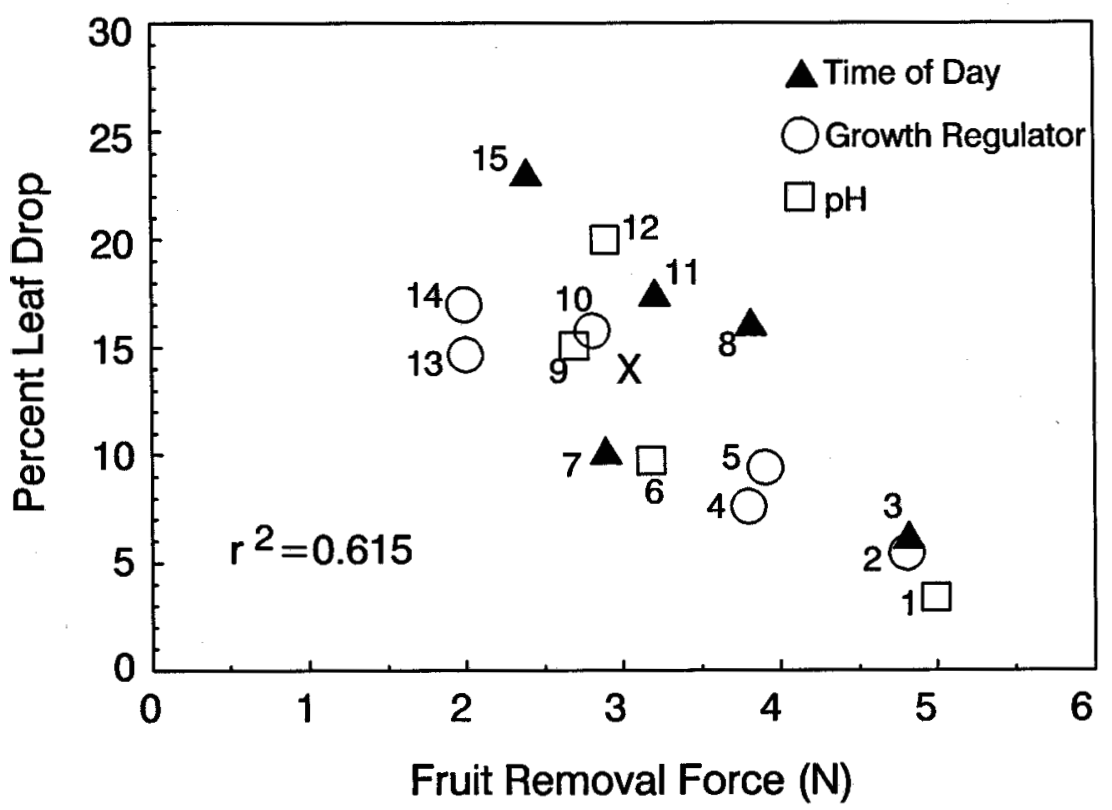

Fig 3. Bivariant plot of all treatments. There is a strong, negative linear relationship between declining fruit-removal force and increasing percent leaf drop $\left(r^{2}=0.615\right)$. The two processes seem to be interconnected, but pedicels may be more sensitive to ethylene than are petioles. Treatments: 1) pH control, 2) growth regulator control,

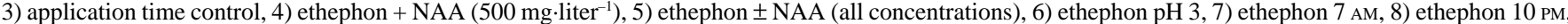
9) ethephon $\mathrm{pH} 7,10)$ ethephon alone (growth regulator experiments), 11) ethephon $5 \mathrm{PM}, 12$ ) ethephon pH 5, 12) ethephon + BA (all concentrations), 14) ethephon + BA (50 mg.liter $\left.\left.{ }^{-1}\right), 15\right)$ ethephon $12 \mathrm{PM}$; X) mean of all treatments containing ethephon.

Martin et al., 1981). Any factor that reduces FRF or percent LD from this point will add to ethephon's effectiveness.

Increasing harvest effectiveness of ethephon on olive will probably be achieved by studying the surface characteristics of petioles and rachides, with an eye toward decreasing petiole penetration or increasing rachis penetration. Progress may be made using surfactants. Our research suggests that a low solution $\mathrm{pH}$ is best; higher $\mathrm{pH}$ results in higher petiole penetration and percent LD. Our research and that of others indicate that applying ethephon under relatively cool, moist conditions is more effective than under warmer, drier conditions.

\section{Literature Cited}

Banno, K., G.C. Martin, and R.M. Carlson. 1993. The role of phosphorous as abscission-inducing agent for olive leaves and fruit. J. Amer. Soc. Hort. Sci. 118:599-604.

Beaudry, R.M. and S.J. Kays. 1987. Effects of physical and environmental factors on the release of ethylene from(2-chloroethyl)phosphonic acid and (2-chloroethyl)-methyl-bis-(phenylmethoxy)silane. J. Amer. Soc. Hort. Sci. 112:352-359.

Ben-Tal, Y. and S. Lavee. 1976a. Increasing the effectiveness of ethephon for olive harvesting. HortScience 11:489-490.

Ben-Tal, Y. and S. Lavee. 1976b. Ethylene influence on leaf and fruit detachment in Manzanillo' olive trees. Scientia Hort. 4:337-344.

Biddle, E., D.G.S. Kerfoot, Y.H. Kho, and K. E. Russell. 1976. Kinetic studies of the thermal decomposition of 2-chloroethyl-phosphonic acid in aqueous solution. Plant Physiol. 58:700-702.

Bukovac, M.J., F. Zucconi, R.P. Larsen, and C.D. Kesner. 1969. Chemical promotion of fruit abscission in cherries and plums with special reference to 2-chloroethylphosphonic acid. J. Amer. Soc. Hort. Sci. 94:226230.

Cooke, A.R. and D.1. Randall. 1968. 2-Haloethanephosphonic acids as ethylene releasing agents for the induction of flowering in pineapples. Nature 218:974-975.

Denney, J.O. 1982. Thermal constraints on the productivity of the olive
(Olea europaea L.) in the climates of olive-producing regions and of Texas. MS thesis. Texas A\&M Univ., College Station, Tex.

Denney, J.O., G.C. Martin, R. Kammereck, D.O. Ketchie, J.H. Connell, W.H. Kreuger, J.W. Osgood, G.S. Sibbett, and G.A. Nour. 1993. Freeze damage and coldhardiness in olive: Findings from the 1990 freeze. California Agr. 47(1):1-12.

Epstein, E., I. Klein, and S. Lavee. 1977. The fate of 1,2-'4C-(chloroethyl) phosphonic acid (ethephon) in olive (Olea europaea). Physiol. Plant. 39:33-37.

Flore, J.A. and M.J. Bukovac. 1982. Factors influencing absorption of ${ }^{14} \mathrm{C}$ (2-chloroethyl)phosphonic acid by leaves of cherry. J. Amer. Soc. Hort. Sci. 107:965-968.

Fridley, R.B., J.J. Mehlschau, H.T. Hartmann, and S.H. Logan. 1973. Mechanical harvesting of olives. Trans. Amer. Soc. Agr. Eng. 16:58-61. Hartmann, H.T. 1973. Chemicals to promote fruit abscission of olives. Acta Hort. 34:379-383.

Hartmann, H.T., A.J. Heslop, and J. Whisler. 1968. Chemical induction of fruit abscission in olives. California Agr. 22:14-17.

Hartmann, H.T., W. Reed, and K. Opitz. 1976. Promotion of olive fruit abscission with 2-chloroethyl-tris-(2-methoxyethoxy)-silane. J. Amer. Soc. Hort. Sci. 101:278-281.

Hartmann, H.T., W. Reed, J.E. Whisler, and K.W. Opitz. 1975. Mechanical harvesting of olives. California Agr. 29:4-6.

Hartmann, H.T., A. Tombesi, and J. Whisler. 1970. Promotion of ethylene evolution and fruit abscission in the olive by 2-chloroethanephosphonic acid and cyclohexamide. J. Amer. Soc. Hort. Sci. 95:635-640.

Hewitt, W. B. 1938. Leaf-scar infection in relation to the olive-knot disease. Hilgardia 12:41-71.

Jacobini, N. and A. Tombesi. 1973. Chemical aids to the mechanized harvesting of olives. Acta Hort. 24:385-389.

Kays, S.J. and R.M. Beaudry. 1987. Techniques for inducing ethylene effects. Acta Hort. 201:77-116.

Klein, I., E. Epstein, S. Lavee, and Y. Ben-Tal. 1978. Environmental factors affecting ethephon in olive. Scientia Hort. 9:21-30.

Klein, I., S. Lavee, and Y. Ben-Tal. 1979. Effect of water vapor pressure on the thermal decomposition of 2-chloroethyl-phosphonic acid. Plant Physiol. 63:474-477. 
Lamouria L.H. and H.T. Hartmann. 1959. Studies of methods of harvesting olives mechanically. Proc. Amer. Soc. Hort. Sci. 73:203-212.

Lang, G.A. 1987. Physiological studies of ethylene-induced olive (Olea europaea L.) fruit and leaf abscission. PhD diss. Univ. of California, Davis.

Lang, G.A. and G.C. Martin. 1985. Ethylene-releasing compounds and the laboratory modeling of olive fruit abscission vs. ethylene release. J. Amer. Soc. Hort. Sci. 110:207-211.

Lang, G.A. and G.C. Martin. 1986. ${ }^{31}$ P-NMR monitoring of ethephon in olive leaves. J. Amer. Soc. Hort. Sci. 111:577-581.

Lang, G.A. and G.C. Martin. 1987. Ethylene-induced olive organ abscission: Ethylene pulse treatments improve fruit-to-leaf abscission ratios. Acta Hort. 201:43-52.

Lang, G.A. and G.C. Martin. 1989. Olive organ abscission: Fruit and leaf response to applied ethylene. J. Amer. Soc. Hort. Sci. 114:134-138.

Lavee, S. and A. Haskal. 1976. Further field studies of the mode of application and efficiency of various ethylene-releasing chemicals to facilitate olive fruit harvest. Riv. Ortoflorofrutt. Ital. 60:166-175.

Martin, G.C., S. Lavee, and G.S. Sibbett. 1981. Chemical loosening agents to assist mechanical harvest of olive. J. Amer. Soc. Hort. Sci. 106:325-330.

Maynard, J.A. and J.M. Swan. 1963. Organophosphorus compounds. I. 2chloro-alkylphosphonic acids as phosphorylating agents. Austral. J. Chem. 16:596-608.

Olein, W.C. and M.J. Bukovac. 1978. The effect of temperature on rate of ethylene evolution from ethephon and from ethephon-treated leaves of sour cherry. J. Amer. Soc. Hort. Sci. 103:199-202.

Olien, W.C. and M.J. Bukovac. 1982. Ethylene generation, temperature responses, and relative biological activities of several compounds with potential for promoting abscission of sour cherry fruit. J. Amer. Soc. Hort. Sci. 107:1085-1089.

Polito, V.S. and S. Lavee. 1980. Anatomical and histochemical aspects of ethephon-induced leaf abscission in olive (Olea europaea L.). Bot. Gaz. 141:413-417.

Polito, V.S. and V. Stallman. 1981. Localized cell growth in ethephontreated olive leaf abscission zone. Scientia Hort. 15:341-347.

Reed, N.M. and H.T. Hartmann. 1976. Histochemical and ultrastructural studies of fruit abscission in the olive after treatment with 2-chloroethyl-tris- (2-methoxyethoxy)silane. J. Amer. Soc. Hort. Sci. 101:633637.

Sibbett, G.S., L. Ferguson, D. Anderson, M.W. Freeman, and G. Welch. 1986. Timing manzanillo olive harvest for maximum harvest. California Agr. 40:19-22.

Tiefengraber, T.B., K.G. Weis, G.C. Martin, H. Yamada, and B.D. Webster. 1994. Phosphorous effects on olive leaf abscission. J. Amer. Soc. Hort. Sci. 119:765-769.

Vitagliano, C. 1969. Richerche sull'impiego di prodotti chimica atti a facilitare la ricuolta della olive. Frutticoltura Ital. 31:439-446.

Warner, H.L. and A.C. Leopold. 1969. Ethylene evolution from 2-chloroethyl-phosphonic acid. Plant Physiol. 44:156-158.

Weis, K.G., R. Goren, G.C. Martin, and B.D. Webster. 1988. Leaf and inflorescence abscission in olive. I. Regulation by ethylene and ethephon. Bot. Gaz. 149:391-397.

Weis, K.G., B.D. Webster, R. Goren, and G.C. Martin. 1991. Inflorescence abscission in olive: anatomy and histochemistry in response to ethylene and ethephon. Bot. Gaz. 152:51-58.

Yang, S.-F. 1969. Ethylene evolution from 2-chloroethylphosphonicacid. Plant Physiol. 44:1203-1204. 